\title{
Intellectual Capital as a Core Competency for Competitive Advantage: A Case Study
}

Nazem M.M. Malkawi, Kalid Al Omari, AzmiHalasa

Economic and Business College

Jadara University, Irbid, Jordan

n_malkawi@hotmail.com

registrar1994@gmail.com

a_halasa@hotmail.com

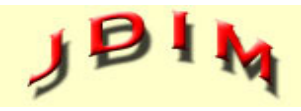

Journal of Digital Information Management

\begin{abstract}
This paper aimed to study intellectual capital as a core competency for competitive advantage at pharmaceutical companies in Jordan. To complete the study, a case study was instituted by analyzing the responses of the pharmaceutical companies; the data collected were analyzed with a statistical package. The study concluded some results, the most appearing were; pharmaceutical companies depend on intellectual capital at a high level, competitive advantage also high, and there is a significant statistical effect of intellectual capital on competitive advantage as a whole and on all its indicators (leadership, human recourse, innovation, processes, and financial excellence) at $(\alpha \leq 0.00)$. Researchers recommend pharmaceutical companies management and staff to reinforce using intellectual capital at all levels and functions and use it as a main source for competitive advantage in all its areas.
\end{abstract}

Subject Categories and Descriptors:

[G.3 Probability And Statistics]: [J.1 Administrative Data Processing 1; Business

General Terms:

Innovation in Business; Organizational Analysis

Keywords: Intellectual Capital, Competitive Advantage, Pharmaceutical companies, Jordan

DOI: $10.6025 / \mathrm{jdim} / 2018 / 16 / 4 / 192-202$

Received: 3 March 2018, Revised 21 April 2018, Accepted 30 April 2018

\section{Introduction}

The world has seen over many transformations including globalization, economic changes, the GATT, openness of market, and hyper competition, which lead to the effects on the local, regional and global level, prompting many scientists to search for new entrances and new strategies to deal with those challenges and changes in business organizations (Hilaly, 2011).

Accordingly, the work in organizations have changed. After they focused on the regulatory physical side of management process, which lead to lose spirit or character of the human, the employees' frustration and consumers indignant is evident. It becomes focused on the human side of the administrative process of practical sense and the promise of effective leadership elements to enable workers and pay attention to intellectual capital (Alia Arif, 2010).

Many strategists believe that in spite of the importance of human resource development each year, it should draw attention to a special category of human resource underlying mostly growth and prosperity of organizations and societies. This source has the experience, knowledge and creativity, which we must develop, and invest in it. Maintaining it is required in spite of the hyperactive competition for skilled workers. These planners go further and ensure the strategic outlook for this category which must be transformed as it is seen as a source of competitive advantage and it becomes the main issue in today's business, that can be explored and exported as part of the so-called "intellectual capital" (Abdul Rahman 
Hijan, 1427Hijri).

Therefore, this study is trying to find out the role of intellectual capital in achieving competitive advantage at pharmaceutical companies in Jordan.

\section{Need of the Study}

This study highlights on intellectual capital, its benefits, challenges and its role in competitive advantage in Pharmaceutical Companies in Jordan. This study considered one of the few studies about Pharmaceutical Companies in Jordan, which sheds light on correlating intellectual capital with a competitive advantage in these companies. The Pharmaceutical sector is a promising and competitive sector in Jordan, reach many countries in exporting medicine, and rely on innovations and effective processes in doing the work, which come from accumulated intellectual capital to grow and expand their work to compete in the world environment. In the last few years, this sector has suffered from many challenges, resulted from political conditions in middle east and closed boundaries around the Jordan, besides poor resources, taxes and so on. All these issues impose challenges for the companies. Depending on creating and building intellectual capital, these companies give chances to overcome challenges. So studies like this can open horizons for these companies through intellectual capital adoption to innovate, survive, grow, and compete.

\section{Literature Review}

\subsection{Intellectual Capital}

The use of the term intellectual capital, explicitly in accounting and administrative writings starts in the nineties of the last century. (Al-Ali, 2003: 10). It first introduced by Luca Pacioli in 1994 who was trying to measure tangible assets linked to factors of production, and when Skandia, the giant Swedish insurance company, developed the Skandia Navigator to measure and report its intellectual capital (IC) (Alhusban \& Ragsdell, 2014). It is believed that this concept will gain wide significance in the third millennium as a key element for creating future wealth of the organization and its survival. Nowadays, the interest of intellectual capital has increased as the market to book value of companies increase in knowledge based organizations such as Facebook, Google, and Wikipedia etc. The value is many times higher than that in traditional organizations. A simplified definition of intellectual capital is the difference between market value and book value, or the value of intangible assets. Intellectual capital includes intellectual material - Knowledge, information, intellectual property, experience- that can used to create profit. A simple formula for intellectual capital was proposed by Dow Chemical collaborated with Skandia 'Intellectual Capital = Human Capital + Organizational Capital + Customer Capital'. Where human capital is the capability of employees to solve customer problems supported by structural capital (organizational capital and customer capital) (Jashapara, 2011).
The intellectual capital is the key for the development. When the gap occurs between intellectual capital and the rest of the capital, we must be interested in it through the attention in employees in terms of training, preparation, deepen the experience and support of administrative capacity. While the employees setting becomes to the fullest, the development and support of the rest of the capital become easier, so organizations should aspire to the growth and progress of work on the development and increased interest in intellectual capital. Actually, knowledge and intellectual capital inextricably bound up with human cognition, reusing, diffusing and maintaining knowledge and intellectual capital should be a participatory activity of all the involved people (Malkawi, 2016).

The intellectual capital in the competitive economy and the information age has become the real capital of the organizations, as a component, which plays the main role in the innovation process, which is the engine of the process of change and innovation. Thus, it is capable of turning knowledge into value and then into a competitive advantage, which means the main element in the generation of value has moved from the exploitation of natural resources (physical) to the exploitation of intellectual assets. All organizations are facing a great challenge to adapt to these changes, and this will not happen unless they own qualified people with the provision of an organizational culture characterized by creativity and innovation. By that, the center of gravity of the economic and social growth has moved to knowledge and human resources element rather than material and financial resources (Naja Abdullah \& Sahnoun, 2011).

The intellectual capital is expressed in the experiences, knowledge and achievements, that is owned in all or some members of the organization which enable them to contribute in the development of performance and gives it a competitive advantage, which is not available to others. Therefore, we can say that intellectual capital (AbdulrahmanHijan, 1427 Hijiri):

- Seeks to strengthen the competitive advantage of the organization.

- Represents part of the human capital of the organization.

- It is the knowledge that collected and clarified to achieve competitive advantage.

- Includes workers who possess the abilities and skills, which are not available in others.

-Works on the production of new ideas or developing old ideas.

The International Federation of Accountants (IFAC, 1998), defined the intellectual capital as a term which is usually used in tandem with all of the intellectual property and assets of intellectual knowledge, as it can be seen as a store of total capital, or rights build on the knowledge and owned by the organization. It also represents the final product of the process transforming knowledge into 
intellectual property or assets of the organization. Whereas (Mention, 2012: 3) defined intellectual capital as the skills available in the organization with extensive knowledge that make them able to make a global organization by responding to customer requirements and the opportunities offered by the technology group. It is a set of intangibles (resources, capabilities and competences) that drives organizational performance and competitive strategy.

(Gruian, 2011: 260) indicates that we must distinguish between the concept of intellectual capital, physical capital and human capital, as the physical capital embedded in the resources that appear in the organization's budget such as real estate, equipment and others, while human capital represents the skills, creativity and expertise accumulated in humans. He pointed out that intellectual capital differs from physical capital, but it is not different from the human capital as it represents one of the intellectual capital components.

As per Marr, (2004: 560), the intellectual capital is the knowledge assets owned by the group organization and contribute effectively to improve their competitiveness by adding value to the stakeholders of the organization. By this the intellectual capital is the mental capacity of a certain group of human resources represented by the talent capable of generating ideas on the development of creative and strategic systems, activities, operations and strategies to ensure the organization possess as a sustainable competitive advantage.

According to Bontis, (2001: 45) intellectual capital consists of the following components:

- Human Capital (Human Capital): They save the knowledge in the minds of the individual worker. The organization does not own this knowledge, but it is linked to the individual person as, skills, creativity, experience etc.

- Structural Capital: Includes the structural ability to move and develop initiatives, by taking into account expectations, methods, concepts and new ideas, which include culture, organizational models, processes, and procedures.

- Intellectual Property (Capital Renewal): Includes the elements, which allow the organization to renew, and protected legally, such as patents, trademarks, investment rights, publishing talent, conferences. Organizations are looking for talent employees to increase intellectual property to achieve a competitive advantage, which enables them to cope with the intense competition in the markets.

- Relational Capital: It reflects the nature of the relations between the organization, its customers, suppliers and competitors.

The importance of intellectual capital is that it represents in itself a competitive advantage of the organization, (Ghen, et al, 2004: 5). And organizations can obtain many benefits through attention to intellectual capital as: it increases the creative ability of employees, attract customers, strengthen loyalty, enhance competition time by offering more and new products, or cutting-edge, reducing product life cycle, lower costs, the possibility of selling at competitive prices, improve productivity, and enhance competitiveness (Hamadani \& Ali 2010: 126; Alchukrgi \& Mahmoud 2010: 8). Therefor-measuring IC is a very important issue; it includes identifying and assigning metrics or indicators to assess the use of the organization's knowledge resources, which not easy to measure by accounting-financial report system that is being used today, date back more than 500 years. IC reporting reflects the efforts undertaken in the IC management and measurement practices, and communicates them with internal and external stakeholders with the aim of showing the organization's invisible (intangible) sources to achieve competitive advantages (MERITUM Project 2002).

\subsection{Competitive Advantage}

The competitive environment globally, regionally, and locally is putting immense pressure on companies to keep track of changes in technology, customer demands, and market trends (Margaret, 2012). Competitive advantage is a business concept that describes the attribute of allowing an organization to outperform its competitors. These attributes may include access to natural resources, low-cost power source, skilled labor, location, high entry barriers, etc. Intellectual capital and access to new technology also considered as a core competency for competitive advantage. (https://en.wikipedia.org/wiki/ Natural_resource). It is argued that organizations can substitute tangible assets and resources, but they are unlikely to do that with intangible assets, tangible assets are not sources of competitive advantage because they can be easily imitated and substituted, in contrast intangible assets are hardly imitated and substituted and provide sustainable competitive advantage (Yaseen; Dijani \& Hassan 2016).

Michael Porter defined the two ways in which an organization can achieve competitive advantage over its rivals: cost and differentiation advantages. Cost is a business strategy provides the same products and services as its competitors, albeit at a lesser cost. Differentiation strategy is a business strategy provides better products and services as its competitors. In Porter's view, strategic management should be concerned with building and sustaining competitive advantage (Porter, 1985). Competitive advantages are the conditions that allow a country or company to produce goods and services ina fashion that is more desirable or lower price for customers. These conditions allow the productive entity to generate more sales or superior margins than its competition. Competitive advantage attributed to a variety of factors, including distribution network, quality of product offerings, brand, cost structure, intellectual property and customer support. (http://www.investopedia.com/terms/c/competi- 
tive_advantage.asp\#ixzZ4Zrk02hpl).

The competitive advantage is known as "the ability to produce goods and services in good quality, at the right price at the right time, and meets the needs of consumers more efficiently than other competitors" (Mustafa Mahmoud, 2006: 13). (Seleim et al, 2007: 790) (Jeradat et al 2012: 400) see that the competitive advantage achieved by discovering new ways to be more effective than those used by competitors. Competitive advantage also defined as the ability to withstand competitors in order to achieve the objectives of profitability, growth, stability, expansion, innovation and renewal, institutions continuously strive to improve competitive positions periodically due to the continued influence of local and global variables (Al-Najjar, 2000).

In order to have an effective competitive advantage; organizations must outdo its competitors, and to be difficult to imitate with the need to ensure continuity. This simply means the company's ability to deliver a product or service that is difficult to imitate by competitors, which will attract more customers and increase market share for the company compared to competitors, as well as improving workers, and the foreign mental picture of trends towards the company. A number of important forces like: capabilities of the technology, pressures on the particular organization or its industry to improve performance, application feasibility, regulations, and so on, may affect the pace and effectiveness of progress in using information and intellectual assets in achieving competitive advantage and delivering business benefits (Malkawi et. Al., 2010). Therefore, to remain at the forefront, organizations need a good capacity to retain, develop, organize, and utilize their employees' capabilities. Intellectual capital appears to be regarded as increasingly important features for organizational survival (Gogan, 2014).

There are a number of reasons why competitiveness has become a cornerstone of the new business system which in fact represents the results of globalization and the movement of variables. These are (Rafafi, (2014):

1. There area number of opportunities in the global market because of the liberalization of international trade.

2. There is an abundance of information on the various markets, because of the development of market research methods and the transparency of the various institutions in the information related to the market and other information that are indicative of their competitive positions.

3. Easy communication and exchange of information between different units and branches of enterprises, thanks to the Internet, and other modern communication mechanisms.

4. Flow of research results, technical developments and acceleration of various processes of creativity and innovation.
5. Increasing production capacities, high levels of quality, ease of entry of new competitors in the market-intensive industries, which has transformed the market into a strong buyers' market where customers have the opportunity to choose between different alternatives to satisfy their desires at the lowest cost and conditions. The only way to deal in the market is by working on acquiring and developing competitive capabilities.

(Abboud 1999: 9) determined several sources of competitive advantage such as:

- Innovation and continuous improvement, which means the introduction of new ideas on the product or service provided, which ensures the continuity of the company from the competition.

- Time achieved through the reduction of product life cycle and reduces waiting time spent by the customer from the time of the product or service request to the time met.

- Knowledge that is intended to expertise and experience accumulated by individuals working in the company.

For the purpose of this study, the research uses the following sources (capabilities) of competitive advantage. If they well manage, they can increase the competitive advantage indicators like price, quality, product or service excellence, flexibility and time. These sources (capabilities) are:

- Leadership

- Human Recourses

- Innovation.

- Processes; and

- Financial excellence.

These sources if become intellectual/knowledge-based they expected to cause an increase in competitive advantage indicators, because of the intellectual capital like trademarks, trading secrets, patents, and so on, to form a core competency and critical success factors for organizations. It leads to achieve competitive advantage if they are managed well in a continuing process and applied in the organizations' competitive capabilities (Leadership, Human Recourses, Innovation, Processes, Financial excellence.)

\section{Related Studies}

Louisa (2016) viewed the intellectual capital role in achieving competitive advantage at economic institutions in the light of the knowledge economy, in a case study in the cement company AinTuta - Batanah. This study addressed the intellectual capital as a role in achieving competitive advantage in a knowledge-based economy in the AinTuta cement company. The study found a significant relationship between intellectual capital and competitive 
advantage in the company under study, and recommended increased attention to intellectual capital and managing it as an important source to achieve excellence, and the need to deal with the intellectual capital as the most important strategic resource is held by the company.

Yaseen, Dijani and Hassan (2016) found the impact of intellectual capital on competitive advantage in a study on the Jordanian Telecommunications Companies. This study investigated the impact of intellectual capital on competitive advantage. This study found the intellectual capital in the form of variables in the structural capital and relational capital highly affect the competitive advantage in these companies.

Jaara and Elkotayni (2016) investigated the effect of intangible assets internally generated (development costs and patents) in the market value of pharmaceutical companies in Jordan. The study has the population of financial employees (Auditors, analysts, accountants) working with Jordanian pharmaceutical companies. The results showed that investment in intangible assets affect maximizing the market value of Jordanian pharmaceutical companies. It is also shown to maintain the confidentiality of information of manufacturing of patents to conserve the competitive position of the pharmaceutical companies for a long time. The study recommends Jordanian pharmaceutical companies to maximize their competitiveness through development costs and patents.

(Khalique Muhammed et al., 2015) evaluated the relationships between the intellectual capital subcomponents and organizational performance in small and medium companies in the electrical and electronic industries in Pakistan. The results showed the appropriateness of intellectual capital components in the degree of their impact on organizational performance. While the only component which is human capital has not proved its effect and has not been significant in influencing the organizational performance.

Chahal \& Bakshi (2014) conceptualized the framework of intellectual capital. It discusses the role of innovation in the relationship between intellectual capital and competitive advantage. It takes into consideration the moderating role of learning in the relationship between intellectual capital and innovation as well as intellectual capital and competitive advantage. The study also seeks to explore the impact of intellectual capital on competitive advantage and business performance. The study, based on review of literature based on intellectual capital, competitive advantage, business performance, and innovation. The conceptual nature of the study is the main limitation.

Taie (2014) studied the effect of intellectual capital on organizational competitive advantage in Egyptian hospitals. Results indicated that structural capital and competitive advantage variables were high and have very high means. In addition, the intellectual capital positively correlated with the competitive advantage.

Bdaiwi (2012)'s study aimed to clarify the correlation between intellectual capital and competitive advantage in telecommunications companies in order to clarify the availability of intellectual capital in those organizations, its role in supporting sustainable competitive advantages, and explain patterns of interest with its different dimensions in the companies under study. The study finds out that the interest in intellectual capital is not regaining enough attention, which reflected on the competitive advantage for these companies.

Fayoumi (2010) did a comparison study of a sample of the Jordanian public and private universities. The study aimed to detect the effect of intangible assets in achieving competitive advantage in light of the adoption of quality management in the Jordanian public and private university standards. The study found the presence of the impact of intangible assets with its elements, human capital, regulatory capital, customer capital, information, capital on total quality management standards, and the presence of the standards of total quality to achieve competitive advantage in the public and private universities' management.

KOÇOöLU; øMAMOöLU; øNCE's (2009) work relies on literature by proposing a theoretical model considering the relationship of intellectual capital with the creation of competitive advantage in knowledge intensive organizations. The study showed that, human capital, organizational capital and relational capital positively influence competitive advantage.

\section{Methodology}

\subsection{Importance of the Study}

Companies today living at a hyperactive competition in the global business environment, and use many resources and tools to grow and survive, with fast development of technology. The intellectual capital comes as a most important source of competitive advantage. So, the output of this research will show the level of pharmaceutical companies interested in the intellectual capital, the level of using it in achieving competitive advantage, as well as how to exploit the intellectual capital in competitive advantage. It will help them to understand how to sustain competitive advantage and have innovations.

\subsection{Problem Statement}

How to sustain the competitive advantage of the changing global economy becomes the most important issue today; on the other hand, relying on intellectual capital as a source of competitive advantage becomes a hot issue; but still our organizations don't benefit highly from this advantage or don't rely on it at all. As other sector in Jordan pharmaceutical companies faces many challenges in this decade because of closing of neighboring markets, going to world markets involves stiff competition, and needs high intensive knowledgeable product and 
continuing product development. Intellectual capital may give solutions to this issue. Therefore, research on this topic is very important to pharmaceutical companies in Jordan, and the results of this study give these companies new horizons to sustain its competitive advantage.

\subsection{Objectives of the Study}

The general purpose of this study is to find out the role of intellectual capital on competitive advantage of pharmaceutical companies in Jordan.

This study aims to:

1. Find out the level of intellectual capital at pharmaceutical companies at pharmaceutical companies in Jordan.

2. Find out the level of competitive advantage at pharmaceutical companies at pharmaceutical companies in Jordan.

3. Find out the effect of intellectual capital on competitive advantage at pharmaceutical companies in Jordan.

4. Using a model for calculating the value of intellectual capitalat pharmaceutical companies in Jordan, if companies permit.

5. Give recommendations in this regard.

\subsection{Hypothesis}

The General hypothesis of the study: There is a significant positive effect at $(\alpha \leq 0.05)$ of intellectual capital on competitive advantage sources (leadership, human resource, innovation, processes, and financial excellence) at pharmaceutical companies in Jordan.

\section{Minor Hypothesis are:}

P1: There is a significant positive effect at $(\alpha \leq 0.05)$ of structural capital on competitive advantage at pharmaceutical companies.

P2: There is a significant positive effect at $(\alpha \leq 0.05)$ of relational capital on competitive advantage at pharmaceutical companies.

P3: There is a significant positive effect at $(\alpha \leq 0.05)$ of intellectual property on competitive advantage at pharmaceutical companies.

P4: There is a significant positive effect at $(\alpha \leq 0.05)$ of human capital on financial excellence at pharmaceutical companies.

\subsection{Procedural Definitions}

Intellectual Capital: Asset of intangible assets or properties (organizational capital, relational (customer) capital, and human capital) that the Jordanian pharmaceutical companies have and develop over time.

Competitive Advantage: The ability of pharmaceutical companies to influence business to outperform better than their competitors. This feature can be achieved depending intellectual based competitive capabilities (Leadership, Human Recourses, Innovation, Processes, and Financial excellence) which lead to provide the best value to customers, such as advertising products or services at lower prices or higher quality for consumers.

Pharmaceutical Companies: Jordanian companies working on producing and marketing medicine over the world.

\subsection{Instrument Development}

Based on validated instruments (Fayoumi, 2010,Hamdani \&Al Abdullah, 2010) and others, we prepared the questions of our survey, which developed to measure the effect of intellectual capital on competitive advantage; we made some modifica-tions to fit our topic content and environment. Two different groups did a review of content validity. The first one contained expert people, who are working with pharmaceutical companies; and the second group contained faculty members, who are interested in intellectual capital and competitive advantage.

Next, we randomly ordered result items for each construct study variables, IC, which contains: human capital, structural capital, relational capital, and intellectual capital sub variables as independent; and dependent variable competitive advantage include: Leadership, Human Recourses, Innovation, Processes, and Financial excellence sub variables.

The survey instrument is comprised of the 5-point Likertscale, which used for measuring the responses. The Likert-scale was based on 1-5 scale, where $1=$ strongly agree and $5=$ strongly disagree. For reliability purposes, all items were tested using Cronbach's alpha and the total is $(0.81)$; so this instrument is reliable and results can be generalized.

Managers develop many models to measure IC, each of them measure a number of IC components and classified them in main categories like Luthy's model, 1998,Jashapara, 2011,Sveiby's model, 2001 and 2010, Guthrei model, 2002 and so on (Alhusban \& Ragsdell, 2014). For the purposes of this study, another model also developed besides questionnaire for measuring the real value of intellectual capital at pharmaceutical companies in Jordan. The significance of this model lies in its ability of providing timely, necessary information for the manager of pharmaceutical companies. These thus enable them to modify their strategies of IC management, according to the specific situation, to obtain and make full use of knowledge, and to achieve long-term competitive excellence. It is represented by equation where, intellectual capital is the difference between market value and book value of the company:

$(I C)=(M V)-(B V)$

Intellectual capital (IC) 
Where book value $(B V)$ is the physical assets documented in records owned by the company.

Market value (MV) is the value of stocks in Amman Financial Market.

After calculating and having the results, attempt to explain sources of intellectual capital through gathering kinds of intellectual capital from real work at companies according to the equation:

Intellectual Capital $(I C)=$ Human Capital $(H C)+$ Organizational Capital (OC) + Customer Capital (CC)

$$
I C=\sum_{i=1}^{n} H C+\sum_{j=1}^{n} O C+\sum_{k=1}^{n} C C
$$

Where human capital is the capability of employees to solve customer problems supported by structural capital (organizational capital and customer capital) and:

Human Capital (HCi): Includes training expense per employee, $R$ \& $D$ investment, years of service with the company, revenues per employee, profits per employee, percent of employees with advanced degrees, IT literacy. Motivation index, savings from employee suggestions, new solutions/product suggestions, training efforts, competence development, employee satisfaction, time in training, re-use of available knowledge, a number of ideas that were turned into projects, interactions with academics, consultants and advisors, talent retention policy, teamwork, and assessment of innovation.

Organizational Capital (Structural) Capital (OCj): Processing time, Contracts filled without error, Number of new products, Number of lessons learnt and best practices applied, patents, registration organizational knowledge, partnerships, existence of social and environmental policies, compliant system, and award scheme.

Customer (Relational) Capital (CCk): Number of new customers, Sales per customer, Time from customer contact to sales response, Average customer duration with the company, Customer satisfaction index/customer rating, Productivity index, Number of processes renewed, Market share, Customers lost, accessing new markets, Customer size, distribution channels, and Relations with suppliers.

Many companies refused to give the real data that measures the intellectual capital completely, and agreed to give indicators only through the questionnaire, prompting researchers to build the model and not apply in the hope of future application in the same sector or other sectors, and thus the second model was used (questionnaire).

\subsection{Study model}

The Figure 1 is the Study model, which shows independent and dependent variables in the proposed model.

\subsection{Sample}

A random purposive sample is selected for data collection. It means to add more reliability to our study. Only the employees, who are most knowledgeable about intellectual capital and competitive advantage are selected to fill the questionnaire. The number of received valid questionnaires was (126), 87 were male, 39 female, 86 bachelors or less, 40 post graduate, 35 top management, and 91 were

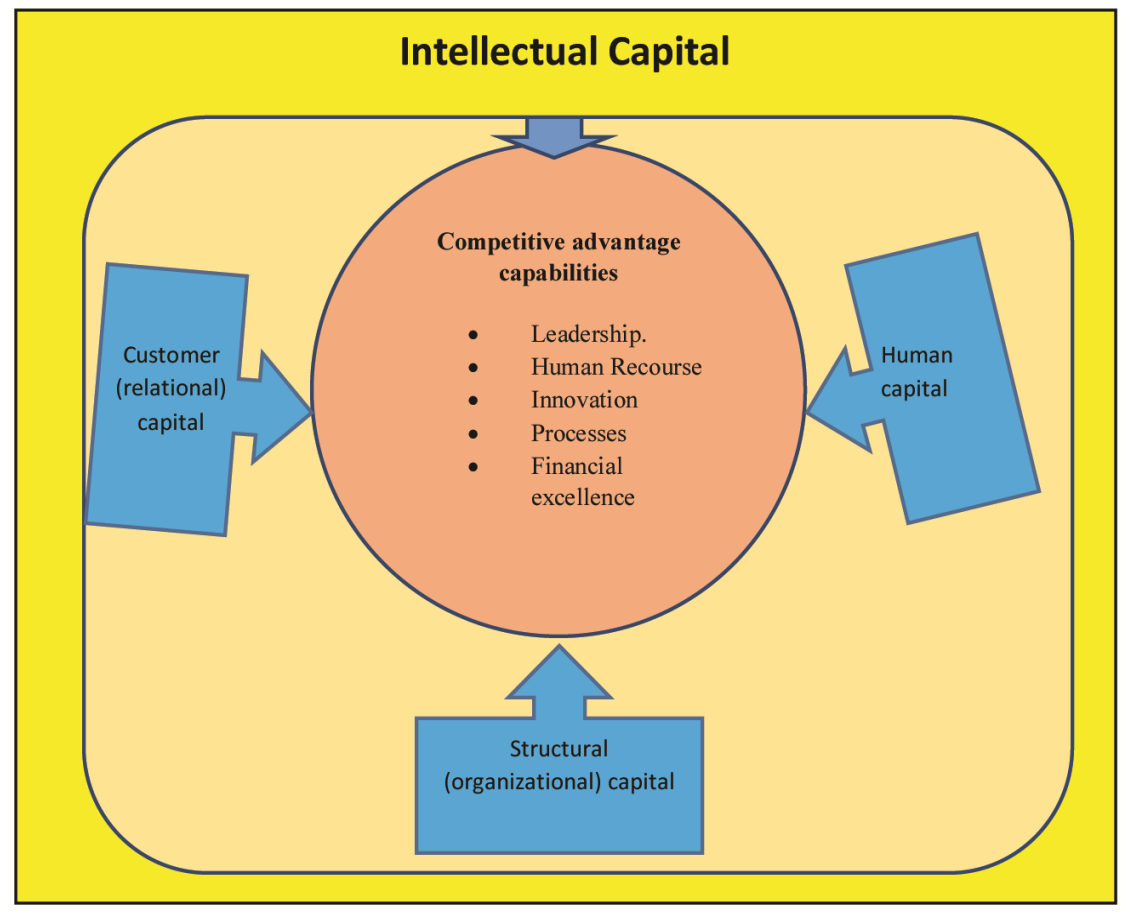

Figure 1. Study model 
middle management.

\section{Results Related to the main Question of the Study}

5.1 What is the role of intellectual capital in competitive advantage at pharmaceutical companies?

To answer this question, researchers extracted the arithmetic means and standard deviations of the areas of study tool, as shown in the table (1).

Table 1 shows that the averages for all areas of study are high. The higher arithmetic average for the Human capital with a mean (4.18), while in the last place was the area Relations, Capital with an arithmetic mean (3.91), and standard deviations are closely indicated to approximated responses in the study sample.

\subsection{This part including the results of study depends on its hypotheses:}

General hypotheses: Intellectual capital has a significant positive effect on competitive advantage sources.

To test this hypothesis, the Multiple Regression is applied, and the table (2) shows the value.
Table 2 shows the following:

1. There is a significant positive impact at $(\alpha \leq 0.05)$ of structural capital on competitive advantage at pharmaceutical companies, where the values of (Beta, $\mathrm{T})$ reached $(0.45,7.73)$, Sig. $(0.00)$ which is compatible with (Taie, 2014).

2. There is a significant positive impact at $(\alpha \leq 0.05)$ of relational capital on competitive advantage. Where the values of (Beta, T) reached $(0.56,8.87)$, Sig. (0.00).

3. There is significant impact at $(\alpha \leq 0.05)$ of intellectual property on competitive advantage. Where the values of (Beta, T) reached $(0.38,9.57)$, Sig. (0.01).

4. There is significant impact at $(\alpha \leq 0.05)$ of human capital on competitive advantage. Where the values of (Beta, T) reached $(0.62,7.43)$, Sig. (0.00).

5. There is a significant positive impact at $(\alpha \leq 0.05)$ of intellectual capital as a whole on competitive advantage, where the values of $(R, R$ Square, adjusted $R$ Square, and $F$ ) reached $(0.68,0.482,0.454$ and 37.43$)$, Sig. (0.00) Therefore the General hypothesis accepted, which is compatible with Yaseen; Dijani; Hassan (2016).

\begin{tabular}{|l|l|c|c|}
\hline Number & Area & Average & Standard Deviation \\
\hline 1 & Structural Capital & 3.97 & 0.44 \\
\hline 2 & Relations Capital & 3.91 & 0.56 \\
\hline 3 & Intellectual property & 4.13 & 0.77 \\
\hline 4 & Human capital & 4.18 & 0.66 \\
\hline Intellectual capital & Leadership & 4.05 & 0.97 \\
\hline 5 & Human Recourse & 4.12 & 0.82 \\
\hline 6 & Innovation & 4.15 & 0.76 \\
\hline 7 & Processes & 3.97 & 0.63 \\
\hline 8 & Financial excellence & 4.05 & 0.52 \\
\hline 9 & & $\mathbf{4 . 0 9}$ & \\
\hline \multicolumn{2}{|l|}{ Competitive Advantage } &
\end{tabular}

Table 1. Arithmetic means and standard deviations of the areas of study tool

\begin{tabular}{|c|c|c|c|c|c|c|c|c|}
\hline Independent variables & Beta & $\mathbf{T}$ & Sig. & $\mathbf{R}$ & R Square & Adjusted R Square & F & Sig. \\
\hline Structural capital & 0.45 & 7.73 & 0.00 & \multirow{4}{*}{0.68} & \multirow{4}{*}{0.482} & \multirow{4}{*}{0.454} & \multirow{4}{*}{37.43} & \multirow{4}{*}{0.00} \\
\hline Relational capital & 0.56 & 8.87 & 0.00 & & & & & \\
\hline Intellectual property & 0.38 & 9.57 & 0.01 & & & & & \\
\hline Human capital & 0.62 & 7.43 & 0.00 & & & & & \\
\hline
\end{tabular}

Predictors: (Constant), Structural Capita, Relations Capital, Intellectual property, Human capital) Dependent Variable: Competitive Advantage

Table 2. Results of Multiple regression between intellectual capital and competitive advantage 


\begin{tabular}{|l|l|l|l|l|l|l|l|}
\hline Dependent variables & Beta & $\mathbf{T}$ & $\mathbf{R}$ & $\mathbf{R}^{\mathbf{2}}$ & $\mathbf{F}$ & Sig. & Acceptance \\
\hline H1: Leadership & 0.460 & 7.310 & 0.682 & 0.465 & 22.434 & 0.00 & Accepted \\
\hline H2: Human Recourse & 0.542 & 8.871 & 0.693 & 0.480 & 35.567 & 0.00 & Accepted \\
\hline H3: Innovation & 0.431 & 4.422 & 0.642 & 0.412 & 12.866 & 0.00 & Accepted \\
\hline H4: Processes & 0.387 & 4.654 & 0.732 & 0.535 & 11.931 & 0.00 & Accepted \\
\hline H5: Financial excellence & 0.352 & 6.376 & 0.791 & 0.625 & 7.745 & 0.01 & Accepted \\
\hline H; Competitive Advantage (Total) & 0.375 & 3.852 & 0.68 & 0.482 & 37.43 & 0.00 & Accepted \\
\hline
\end{tabular}

Table 3. The results of simple regression relationship between intellectual capital and competitive advantage indicators

The results of multiple linear regression analysis in table 2 shows the adjusted $\mathrm{R}$ Square $=0.454$, which means that the model explicated is $0.454 \%$ of the variance in competitive advantage. The whole model was significant based on calculations of $F=37.48$ and $P=0.00$. Therefore the general hypothesis accepted.

Moreover, effect of intellectual capital on each of competitive advantage indicators tested as indicated in table 3.

\section{Independent: Intellectual Capital}

The table highlights the each competitive advantage variable tested for significance. Results indicated that intellectual capital significantly affects all competitive advantage variables (leadership, human resource, innovation, processes, and financial excellence), and interpreted $(0.465,0.48,0.412,0.535$, and 0.625$)$ at $(\alpha \leq$ 0.01 ) of the variance in competitive advantage indicators (leadership, human resource, innovation, processes, and financial excellence) respectably. Table 3 shows the significance of constructs.

\section{Discussion and Implications}

We believe that Jordanian companies in general and pharmaceutical companies in particular in the last decade realize the role of intellectual capital in the new business, and adopt it as a competitive necessity for survival and leading into this sector. Clear understanding and alignment of intellectual capital for competitive advantage is essential to realize the potential benefits to the pharmaceutical companies. This research examined the adoption of intellectual capital for competitive advantage in pharmaceutical companies. We presented an initial adoption and implementation of an intellectual capital in all its variables (structural capital, relational capital, intellectual property, and human capital) for these companies. These intangible assets are to be seen as an important step towards a sophisticated support for competitive advantage in all its variables (leadership, human recourse, innovation, processes, and financial excellence), which are the bases for competitive advantage.
In this study, we examined the effect of independent vari-ables (intellectual capital) on the dependent variable (competitive advantage). The findings of this study indicate that intellectual capital is in high level at pharmaceutical companies in Jordan, where the competitive advantage is also high. There is a significant positive effect of intellectual capital on competitive advantage in all its variables. Pharmaceutical companies are aware of the benefits, which can be gained once they convert to intellectual capital. Furthermore, they were convinced if they adopted intellectual capital, it will give them a competitive edge, depending on competition intensity. On the other hand, companies realize the role of competitive advantage in today's business.

So the first implication of this study is that intellectual capital is the key to success in competitive advantage in all its indicators; this would lead successfully to facilitate intellectual capital adoption. Secondly, because expected benefits have a positive effect on the adop-tion of intellectual capital and competitive advantage, pharmaceutical companies should seek to convert those opportunities into reality and maximize exploiting intellectual capital in achieving competitive advantage, in order to ensure fruit-ful results alongside the shift towards intellectual capital. Thirdly, because of competitive pressure, pharmaceutical companies should take into consideration that intellectual capital and the competitive advantage adoption will give them a sustainable competitive edge.In order to exploit this opportu-nity, they have to move forward to expand using intellectual capital and aware employees about the benefits of this strategy adoption, which is the main implication of this study.

From the above findings, it is possible to conclude that the assimilation of competitive advantage can exist triggered by the intellectual capital adoption. It is unique in its broad analysis of the two related terms, the intellectual capital and competitive advantage. This is an important sector in the economy, which is pharmaceutical.

\section{Recommendations}


Researchers recommended pharmaceutical Companies management and staff to expand using intellectual capital in all types (structural capital, relational capital, intellectual property, and human capital), exploiting intellectual capital in competitive advantage with all its areas (leadership, human recourse, innovation, processes, and financial excellence), and aware employees in these companies about how they can achieve competitive advantage by depending on intellectual capital.

\section{Conclusion}

Following this study model, future research can be conducted in the same sector (pharmaceutical companies) and other sectors like telecommunications, hotels, insurance, industrial companies, etc. Later it is possible to determine their developments in adoption of intellectual capital and competitive advantage. For competitive advantage, future research may use different indicators with more clarification to investigate the real effect on competitive advantage. In addition, future research may use many different factors as moderators, and apply our model in this regard.

\section{Limitations of the Study}

This study faces many limitations such as:

- There is a widespread of companies and the sample is low.

- Some employees do notrealize what intellectual capital is.

- Some companies do not respond effectively to the study, especially in using our model.

\section{References}

[1] Ahronovitz, Miha., et al., (2010), "Cloud Computing Use Cases A white paper produced by the Cloud Computing Use Case Discussion Group", v4, sit http:// cloudusecases. Org/ Cloud Computing use Cases whitepaper-a 0.odt.

[2] Al-Ali, N. (2003). "Comprehensive Intellectual Capital Management: Step by Step”, John Wily \& Sons, Inc., Hoboken, New Jersey, U.S.A.

[3] Abu Bakar, Mahmoud. (2006). "Human Resources entrance to achieve competitive advantage," University House, Alescandria, Eygept.

[4] Alchukrgi, B., Thanon, Mahmoud Musab al-Saleh. (2010). "Measure the head of the intellectual capital and its impact on the profitability of banks," Tikrit Journal of Management and Economic Sciences, Faculty of Management and Economics, University of Tikrit, 6(20).

[5] AbdulrahmanHijan, (1427 Hijiri) "Intellectual capital as a strategy for transforming from public to excellence group", Available at http://abufara.net/index.php/2012 : 10-21-10-56-42/2012-10-21-10-57 16/33- 2013-07-21-15-

\section{6-02/8-000005.}

[6] Bdaiwi, Afaf. (2012) "A Strategic Vision for the Intellectual Capital and its Role in Achieving Competitive Advantage "Field Study", Business College, Alazhar University, Egypt.

[7] Alhusban, M., Ragsdell, G. (2014). Bridging the gapbetween intellectual capital models: an ancestry/ chronology approach. IN:Rooney, J. and Murthy, V. (eds.) Proceedings of the 11th International Conference on Intellectual Capital, Knowledge Management And Organizational Learning, (ICICKM 2014), 6-7 November 2014, Sydney, Australia, p. 477-487.

[8] Bontis, N. (2001) "Assessing Knowledge Assets: A Review of the Models Used to Measure Intellectual Capital", International Journal of Management Reviews, 3(1), (March).

[9] Bo Naja Abdullah, Sahnoun. (2011). "Measurement and disclosure of the intellectual capital methods from the perspective of international accounting standards", the fifth international forum about the "Intellectual Capital in the Arab Business Organizations in the Light of Modern Economies", School of Economics and Commercial Sciences of the Business Science, Hassiba Bin Bu Ali Shelf University, Algeria, 13 - 14 (December).

[10] Chahal, Hardeep, BkshiPurnima. (2014). "Effect of intellectual capital on competitive advantage and business performance: role of innovation and learning culture", International Journal of Learning and Intellectual Capital, 11(1), DOI: 10.1504/IJLIC.2014.059227.

[11] Fayoumi, Ahmed. (2010). "The impact of intangible assets in achieving competitive advantage in light of the adoption of total quality management standards comparative study", Comparison study on a sample of the Jordanian public and private universities, Master Thesis, Department of Business Administration, College of Business, University of the Middle East, Jordan.

[12] Chen, Jin, Zhahuizhu, Yuanxie. (2004). "Measuring Intellectual Capital Anew Model and Empirical Study", Journal of Intellectual Capital, 5(1).

[13] Gruian, C. (2011). "The Influence of Intellectual Capital on Romanian Companies' Financial Performance”, Annales Universities Apulensis Series Economics, 13(2).

[14] Gogan, Maria-Luminita. (2014). "An innovative model for measuring intellectual capital" Procedia - Social and Behavioral Sciences, 124 (2014) 194 - 199.

[15] Hamdani, N. I., Abdullah, Al Abdullah, Akram. (2010). "Capital and intellectual impact on the performance of employees, Analytical study of the opinions of heads of academic departments at the University of Mosul," The magazine Rivers Development, 32(98), College of Management and Economics, University of Mosul, Iraq.

[16] Hilali, Hilali, (2011). "Managing, Measuring, and Developing Intellectual Capital as Part of the Knowledge Management in Institutions of Higher Education," The 
Qualitative Research Journal, Mansoura University, No. 22.

[17] Jashapara, Ashok. (2011). Knowledge Management an Integrated Approach (2e), Prentice-Hall, Financial Time: FT.

[18] Jaara, Osama Omar., Elkotayni, Khalid Abdul Rahman. (2016), "The Impact of Intangible Assets Internally Developed on the Market Value of Companies A Field Study in the Pharmaceutical Companies in Jordan. Accounting and Finance Research. 5(2).

[18] Khalique , Muhammad., Bontis, Nick., Bin Shaari, Jamal Abdul Nassir., Muhammad Isa, Abu Hassan. (2015). Intellectual capital in small and medium enterprises in Pakistan, Journal of Intellectual Capital. 16(1), p.224-238

[19] KOÇÖLU, øpek; øMAMOöLU, Salih; øNCE, Hüseyin. (2009). "The relationship between firm intellectual capital and the competitive advantage", Journal of Global Strategic Management | V. 3 | N. 2 | 2009-June | isma.info | 181-208 | DOI: 10.20460/JGSM.2009318469.

[20] Louisa, Ferhati. (2016) "Intellectual capital role in achieving competitive advantage at economic institutions in the light of the knowledge economy, Case study in cement company AinTuta- Batanah", PhD Thesis.

[21] Mention, A. (2012). "Intellectual Capital, Innovation and Performance: A Systematic Review of the Literature", Business and Economic Research, 2(1).

[22] Marr, B. (2004). "Intellectual Capital - Defining Key Performance Indicators for Organizational Knowledge Assets", Business Process Management Journal, 10(5).

[23] Malkawi, Nazem. (2016). "Executing Knowledge Management 2.0 (KM2.0) through Web 2.0-Applied Study at Jordanian Insurance Companies", International Journal of Business and Social Sciences, 7(10).

[24] MERITUM Project. (2002). Guidelines for Managing and Reporting On Intangibles (Intellectual CapitalReport), [Online], http://www.pnbukh.com/files/pdf_filer/
MERITUM_Guidelines.pdf.

[25] Malkawi, Nazem, Alraja Mansour, AlkierTareq. (2010). Information systems auditing-applied study at banks listed in Syria Stock Exchange, European Journal of Economics, Finance\& Administrative Sciences EJEFAS, Issue 21, (June).

[26] Najm, Abboud. (1999). "Innovation renewable source of competitive advantage," Management News, Volume 28, The Arab Organization for Administrative Development.

[27] Al-Najjar, Farid. (2000). Competition and Applied Promotion (Corporate Mechanisms for Improving Competitive Advantages, Youth League for Publishing, $p$ 10.'

[28] Rafafi, Mohamed. (2014). "Role of Information Technology in Achieving Competitive Advantage in Algerian Economic Institutions", Unpublished Master Thesis, University of Biskra, Algeria. A

[29] Taie, Eman. (2014). "The Effect of Intellectual Capital Management on Organizational Competitive Advantage in Egyptian Hospitals", International Journal of Business and Social Science, 5 (2).

[30] The International Federation of Accountants (IFAC), 1998, http://www.ifac.org.

[31] Seliem, A., Ashour, A., Bontis, N. (2007) "Human Capital and Organizational Performance: A Study of Egyptian Soft Ware Companies, Management Decision, 45(4).

[32] Yaseen, Saad., Dijani, Dima., Hassan, Yaseen. (2016). "The impact of intellectual capital on competitive advantage: Applied study at Jordanian Telecommunications Companies", Computers in Human Behavior, 62, 168-175.

[33] (http://www.investopedia.com/terms/c/competitive_ advantage.asp\#ixzz4Zrk02hpl).

[34] (https://en.wikipedia.org/wiki/Natural_resource). 